\title{
Lehnen, Leila. Citizenship and Crisis in Contemporary Brazilian Literature. New York: Palgrave Macmillan, 2013.
}

Jaime Ginzburg

Citizenship and Crisis in Contemporary Brazilian Literature is highly recommended for researchers interested in Brazilian literary texts. Leila Lehnen, an Associate Professor at The University of New Mexico, in this book, studies texts written by Luiz Ruffato, Fernando Bonassi, Ferrez and Marcus Vinicius Faustini. The results of her work are outstanding.

In the Introduction, "Voices of contestation", we find some of the main topics expected to be discussed along the book. According to Lehnen, "Citizenship and Crisis in Contemporary Brazilian Literature considers how recent literary texts address the socioeconomic and political changes that Brazil has undergone since its 1985 democratic transition and what these alterations have meant for the understanding and performance of citizenship in the literary realm" (p.2). The book's approach regards Brazilian History as a process, in which economic and political changes influence both public and private life.

James Holston's terms "differentiated citizenship" are very important to settle the book's argumentative continuity and unity. The adjective "differentiated" comes up bringing visibility to the difference, concerning most Brazilians, between, on one hand, a theoretical access to rights, and on the other hand, an implementation "far from egalitarian" (p.3). More than a difference, Holston's concept refers to a constitutive antagonism of Brazilian contemporary society.

According to Professor Lehnen, "differentiated citizenship spawns various modes of violence", and "violence, in its turn, accentuates social disjunctures" (p.18). 
The antagonism between an abstract meaning of citizenship (constantly reinforced by political leaders in their public appearances) and the restricted access to rights by many people (especially in contexts related to disempowered groups, poverty and social exclusion), is a constitutive element of social dynamics. The book's point of view is delimited by an ethical concern, regarding the consequences of differentiated citizenship. All the chapters are connected by an ethical criticism, and by an empathy to lives of people who do not have full access - or even a minimum access - to civil rights. Empathy allows the author to see what other readers would not see.

Citizenship and Crisis in Contemporary Brazilian Literature is an insightful reflection. The argumentation is clear and precise. The bibliographical references include relevant books and articles regarding political, social, historical and economic studies. This interdisciplinary approach provides a conceptual frame in which reflections on citizenship are consistent and coherent. Along the book, we find reflections on Contemporary Brazilian society, regarding important issues such as education, mass media, and violence. Citizenship and Crisis in Contemporary Brazilian Literature is not supposed to be restricted to literary debates. By publishing it, Professor Lehnen performs an intervention on conflicts she describes.

Through this intervention, the author criticizes authoritarianism, repression and economic inequality. She brings visibility to discrimination, abuse and displacement. Social awareness, according to the book, relates to aesthetic innovation (p.28). According to the author, texts reflect "the disjointedness that characterizes differentiated citizenship" (p.13). The literary texts investigated by this book are not novels or short stories imprisoned by canonical conventions. Antagonisms in society relate to formal challenging creativity; the negative impact of differentiated citizenship might demand expressions able to go against institutionalized conservative perspectives, confronting 
literary traditional values. As a mediation, the word "disjointedness" can describe both textual ruptures and social conflicts.

"Violence and trauma in Vista parcial da noite" brings up a very important topic, memory. World War II constituted a trauma, which affected a character, constructed by Luiz Ruffato; Professor Lehnen analyses the "split consciousness" of the character, whose discourse expresses the horrors of war - "A sirene! Os aviões! As bombas!" (p.47). Memory is important, as well, in "Repression, neoliberalism and literature", a section dedicated to Fernando Bonassi's "O menino que se trancou na geladeira". According to Professor Lehnen, this 2004 book exposes oppression, in times of Military Dictatorship, as "a part of everyday life" (p.84). Citizenship and Crisis in Contemporary Brazilian Literature focuses on the period since 1985 democratic transition. A historical perspective is necessary to reframe the recent social changes, discussing the meanings we can attribute to the past through the present's eyes. Both "Violence and trauma in Vista parcial da noite" and "Repression, neoliberalism and literature" call our attention, because they discuss these meanings.

A detailed discussion of Luiz Ruffato's is presented in Chapter 1, enlightening his work, focusing on hard issues such as domestic abuse and suicide. Violence is analysed as both a threat and a form of resistance. The political context interacts with aesthetic procedures. From an epistemological perspective, along with the Introduction, Chapter 1 provides the resources, not only to understand the main arguments of the whole book but also, as a pedagogical reference, to figure out as a model of serious and rigorous critical work. Chapter 2, a discussion on Fernando Bonassi, shows conceptual, methodological and interpretative originality. This chapter presents relevant discussions on literary genres. Chapter 3 concerns differentiated citizenship in Ferrez. Giorgio Agamben's Homo Sacer firmly supports the critical perspective. Professor Lehnen goes 
deep into the agonistic grounds of surviving in violent contexts. She also brings up relevant questions on what critics call "literatura marginal" (p.132). Chapter 4 discusses "Cartographies of hope". In Guia afetivo da periferia, we find a perception of periferia as a space integrated to the city of Rio de Janeiro; according to Professor Lehnen, Faustini's book "constructs metaphoric bridges between Rio's different socio-geographic areas". It goes against "the prevalent perception of the periferia as a dangerous zone" (p.173). All chapters discuss differentiated citizenship, constituting a systematic, dynamic and coherent line of interpretation. The results allow us to understand thematic, formal and contextual elements of contemporary Brazilian literature, and to qualify academic debates on Brazilian Studies. 